This is a draft version of a chapter that appears in Robbeets, M and A. Savelyev (eds). The Oxford Guide to the Transeurasian Languages (OUP, 2020)' see https://global.oup.com/academic/product/the-oxford-guide-to-thetranseurasian-languages-9780198804628.

The research leading to these results has received funding from the European Research Council under the Horizon 2020 Program/ ERC Grant Agreement n. 646612 granted to Martine Robbeets.

Chapter 44

\title{
The Transeurasian homeland: where, what and when?
}

\author{
Martine Robbeets
}

\section{Abstract}

The Farming Language Dispersal Hypothesis boldly claims that agricultural dispersal is an important factor in shaping linguistic diversity. This view has been sharply criticized, especially for the regions currently occupied by the Turkic, Mongolic and Tungusic languages, where farming is often unviable. Here, I combine the power of linguistic scholarship with archaeological and genetic research to show that the spread of the Transeurasian languages (i.e. Japonic, Koreanic, Tungusic, Mongolic and Turkic languages) is indeed driven by agriculture. The integration of the three disciplines in a single approach, for which I use the term "triangulation" reveals a sequence of linguistic expansions that can be linked to the spread of millet and rice agriculture as well as to the dispersal of the Ancient North and South East Asian gene pool in Neolithic and Bronze Age North East Asia.

Keywords: Farming Language Dispersal Hypothesis, Transeurasian, triangulation, agriculture, Japonic, Koreanic, Tungusic, Mongolic, Turkic

\subsection{Introduction}

In the previous chapter, we identified a location and a time depth for the homelands of the individual proto-languages at the tip of the Transeurasian family tree and suggested that each ancestral speech community was familiar with agriculture. In this chapter, I will extend the three wh-questions, i.e. where, when and what, to the root 
and the nodes of the Transeurasian family. If Proto-Transeurasian is indeed the original language ancestral to the Japonic, Koreanic, Tungusic, Mongolic and Turkic languages, as suggested in Figure 44.1, a number of new questions arise from this classification $^{1}$ : Who were the ancestral speakers of Proto-Transeurasian? Where did they originally live? When did they live? What motivated the primary break-up of the family? And, when and how did the daughter languages reach their present-day locations?

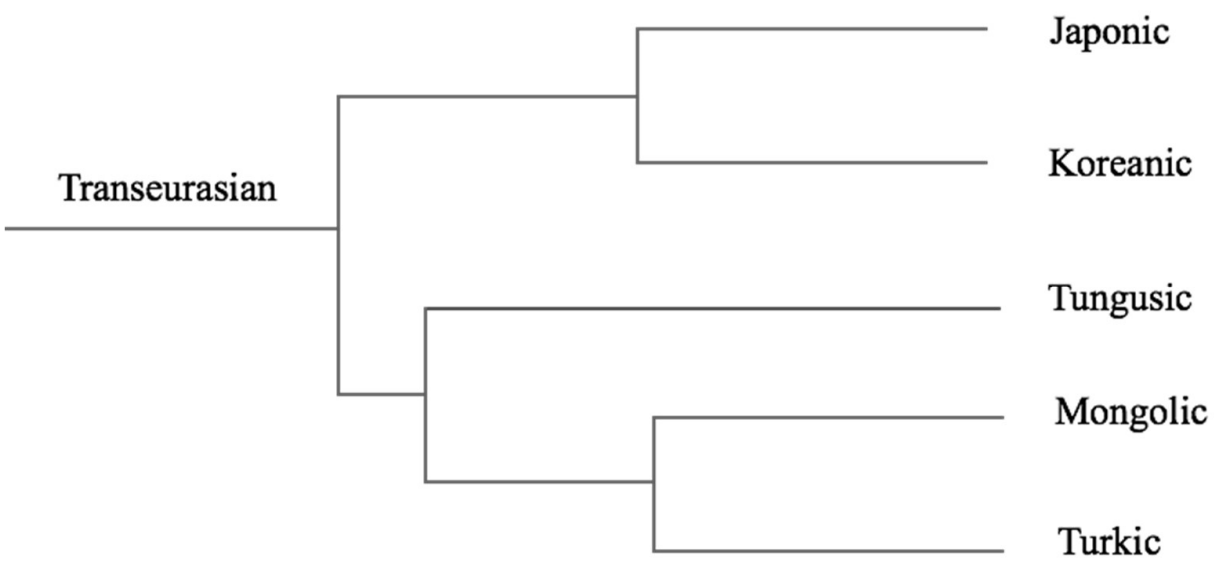

Figure 44.1 The Transeurasian family tree

In this chapter, I will address these questions from an interdisciplinary perspective and challenge the traditional "Pastoralist Hypothesis", which identifies the primary dispersals of the Transeurasian languages with nomadic expansions starting around 2000 BC in the eastern Steppe (Menges 1977; Miller 1990; Dybo 2013).

In the linguistic part of this chapter, I will estimate a date and a location for the ancestral speech communities, in addition to examining the availability of agricultural vocabulary. To this end, I will apply different techniques such as the diversity hotspot 
This is a draft version of a chapter that appears in Robbeets, $M$ and A. Savelyev (eds). The Oxford Guide to the Transeurasian Languages (OUP, 2020)' see https://global.oup.com/academic/product/the-oxford-guide-to-thetranseurasian-languages-9780198804628.

The research leading to these results has received funding from the European Research Council under the Horizon 2020 Program/ ERC Grant Agreement n. 646612 granted to Martine Robbeets.

principle, phylolinguistics and cultural reconstruction. In the interdisciplinary part of the chapter, I will review evidence from genetics and archaeology for the population history and the spread of agriculture in North and East Asia. Finally, I will map the different lines of evidence on each other and argue that the triangulation of the evidence supports a Farming Language Dispersal Hypothesis (Renfrew 1987; Bellwood and Renfrew 2002; Diamond and Bellwood 2003) for the spread of the Transeurasian languages.

\subsection{Linguistic inferences about the Transeurasian past}

44.2.1 Dating of the ancestral speech communities

44.2.1.1 The Proto-Transeurasian speech community

Lexicostatistic dating situates the root of the Proto-Transeurasian tree in the sixth millennium BC (Starostin et al. 2003: 235-236), at 6000 BC (Blažek and Schwarz 2014: 88), or at 4750 BC (Blažek and Schwarz 2009). The Automated Similarity Judgement Program (ASJP) yields a date for Proto-Transeurasian of 6231 BC, be it with a margin of error of $29 \%$, i.e. the time span $7795-4667$ BC (Cecil Brown p.c.). ${ }^{2}$ Cultural reconstruction suggests that the speakers of Proto-Transeurasian were familiar with plant cultivation and weaving (Robbeets 2017f; see Section 44.2.3). Since the earliest Neolithic society in Northeast Asia that was familiar with both plant cultivation and weaving using spindle whorls was the Xinglongwa culture (62005400 BC) (Underhill 2013), we can create a ceiling for the Proto-Transeurasian speech community around $6200 \mathrm{BC} .{ }^{3}$ Bayesian inference estimates the first split in the Transeurasian family at $4700 \mathrm{BC}$ (Robbeets and Bouckaert 2018). In sum, the 
This is a draft version of a chapter that appears in Robbeets, M and A. Savelyev (eds). The Oxford Guide to the Transeurasian Languages (OUP, 2020)' see https://global.oup.com/academic/product/the-oxford-guide-to-thetranseurasian-languages-9780198804628.

The research leading to these results has received funding from the European Research Council under the Horizon 2020 Program/ ERC Grant Agreement n. 646612 granted to Martine Robbeets.

different approaches largely converge on dating the first split in the Transeurasian family around the sixth millennium BC.

\subsubsection{The Proto-Altaic speech community}

Lexicostatistic dating situates the Altaic node in the tree at $4350 \mathrm{BC}$ (Blažek and Schwarz 2009). Starostin et al. (2003: 235-236) remain indecisive as to whether a separate Altaic node can be distinguished or whether Tungusic and Turko-Mongolic dissolved simultaneously along with Japono-Koreanic as distinct branches from Proto-Transeurasian. By consequence, they do not estimate the time depth of ProtoAltaic. Similarly, Blažek and Schwarz (2014: 88) propose a unity between Japonic, Koreanic and Tungusic and therefore do not reach a dating for Proto-Altaic. The Automated Similarity Judgement Program (ASJP) yields 3954 BC with a margin of error between $5688 \mathrm{BC}$ and $2227 \mathrm{BC}$ (Holman et al. 2011: 554). Bayesian phylolinguistics infers the separation time for Proto-Altaic at 3293 BC (Robbeets and Bouckaert 2018). Cultural reconstruction suggests that the speakers of Proto-Altaic practiced agriculture and pig domestication, but probably no pastoralism. As the pastoral terms shared between Tungusic, Mongolic and Turkic can mainly be explained by borrowings from one language into the other (Savelyev 2017), the ProtoAltaic speech community must have preceded $3000 \mathrm{BC}$ and thus existed before the advent of the first pastoralists on the eastern steppes (Taylor et al. 2017). In sum, the different approaches largely converge on dating the break-up of Proto-Altaic to the fifth or fourth millennium BC. 
This is a draft version of a chapter that appears in Robbeets, M and A. Savelyev (eds). The Oxford Guide to the Transeurasian Languages (OUP, 2020)' see https://global.oup.com/academic/product/the-oxford-guide-to-thetranseurasian-languages-9780198804628.

The research leading to these results has received funding from the European Research Council under the Horizon 2020 Program/ ERC Grant Agreement n. 646612 granted to Martine Robbeets.

Lexicostatistic dating estimates that Mongolic and Turkic separated in the fourth millennium BC (Starostin et al. 2003: 236), or at 4600 BC (Blažek and Schwarz 2014: 88). Bayesian methods infer a split at 1552 BC (Robbeets and Bouckaert 2018). If the verb for 'to milk' indeed is a cognate between Turkic and Mongolic (see Section 44.2.3), cultural reconstruction would suggest that the Mongolo-Turkic node postdates the migration of Western steppe herders with diary pastoralism to the eastern steppes around 3000 BC (Warinner et al. 2014; Jeong et al. 2018a). ${ }^{4}$ In sum, whereas lexicostatistic dating points to the fourth millennium $\mathrm{BC}$, cultural reconstruction and Bayesian inference indicate that the Mongolo-Turkic speech community separated in the third millennium BC.

44.2.1.4 The Japono-Koreanic speech community Lexicostatistic dating estimates that Japonic and Koreanic separated in the fourth millennium BC (Starostin et al. 2003: 236), at 2900 BC (Blažek and Schwarz 2009), or at 4300 BC (Blažek and Schwarz 2014: 88). Bayesian methods infer a split at 1847 BC (Robbeets and Bouckaert 2018). As Japonic is thought to have borrowed rice agricultural vocabulary from the Dawenkou culture (4100-2600 BC) after its breakup from Koreanic (see Robbeets et al., this volume: Chapter 43), the separation between Japonic and Koreanic must have predated 2600 BC. In sum, the different approaches converge on dating the break-up of Proto-Japono-Koreanic around the third and second millennium BC.

Table 44.1 Overview of the time depth of Proto-Transeurasian and its daughter branches according to different linguistic dating methods. 


\begin{tabular}{|c|c|c|c|c|}
\hline & $\begin{array}{l}\text { Lexicostatistics } \\
\text { (Blažek and } \\
\text { Schwarz 2009) }\end{array}$ & $\begin{array}{l}\text { Automated } \\
\text { Similarity } \\
\text { Judgement } \\
\text { Program } \\
\text { (Holman et al. } \\
2011 \text { ) }\end{array}$ & $\begin{array}{l}\text { Cultural } \\
\text { reconstruction } \\
\text { (Robbeets 2017) }\end{array}$ & $\begin{array}{l}\text { Bayesian } \\
\text { (Robbeets \& } \\
\text { Bouckaert 2018) }\end{array}$ \\
\hline $\begin{array}{l}\text { Proto- } \\
\text { Transeurasian }\end{array}$ & pre-4750 BC & pre-6231 BC & post- $6200 \mathrm{BC}$ & pre-4700 BC \\
\hline Proto-Altaic & $4750-4350 \mathrm{BC}$ & 6231-3954 BC & pre-3000 BC & $4700-3293 \mathrm{BC}$ \\
\hline $\begin{array}{l}\text { Proto-Japono- } \\
\text { Koreanic }\end{array}$ & $4750-2900 \mathrm{BC}$ & - & pre-2600 BC & 4700-1847 BC \\
\hline $\begin{array}{l}\text { Proto-Turko- } \\
\text { Mongolic }\end{array}$ & - & - & $\begin{array}{l}\text { post } 3000 \mathrm{BC} \\
\text { pre- } 1300 \mathrm{BC}\end{array}$ & $3293-1552$ BC \\
\hline Proto-Tungusic & - & - & pre $200 \mathrm{AD}$ & 3293 BC-200 AD \\
\hline
\end{tabular}

\subsubsection{Location of the ancestral homelands}

\subsubsection{The Proto-Transeurasian homeland}

In the previous chapter, we estimated the location of the speech communities of

Proto-Macro-Turkic, Proto-Macro-Mongolic, Proto-Macro-Tungusic, Proto-Macro-

Japonic, Para-Japonic and Proto-Koreanic at the beginning of the first millennium

BC, as indicated in Figure 44.2. The West Liao River Region is in the core of the relatively compact territory where the proto-languages were once spoken and would thus seem a plausible source for their spread. Given that each of these ancestral speech communities was familiar with agriculture (see Robbeets et al., this volume: Chapter 43) and that the same was probably true for their common ancestral lineages (see Section 44.2.3), it is easy to understand why the languages did not disperse in the 
northern part of the circle drawn in Figure 44.2. Indeed, early agricultural dispersal for these languages was circumscribed by the decreasing temperature towards the north, in what corresponds to present-day Siberia.

Not only is the West Liao River Region in the core of the original spread zone of the Transeurasian languages, it is also here that the greatest linguistic diversity with regard to the deepest subgroups of Transeurasian; linguistic pockets of Korean, Tungusic and Mongolic languages are represented in the area. Moreover, the Koguryo people, who are associated with what is likely a sister of Proto-Japonic were first attested in that area within the context of the Puyo state (ca. 300 BC-346 AD; Robbeets 2015: 25). Even if this diversity hotspot principle is not full proof (Robbeets 2017b), it can give us a rough indication of a plausible location for the Transeurasian homeland. 


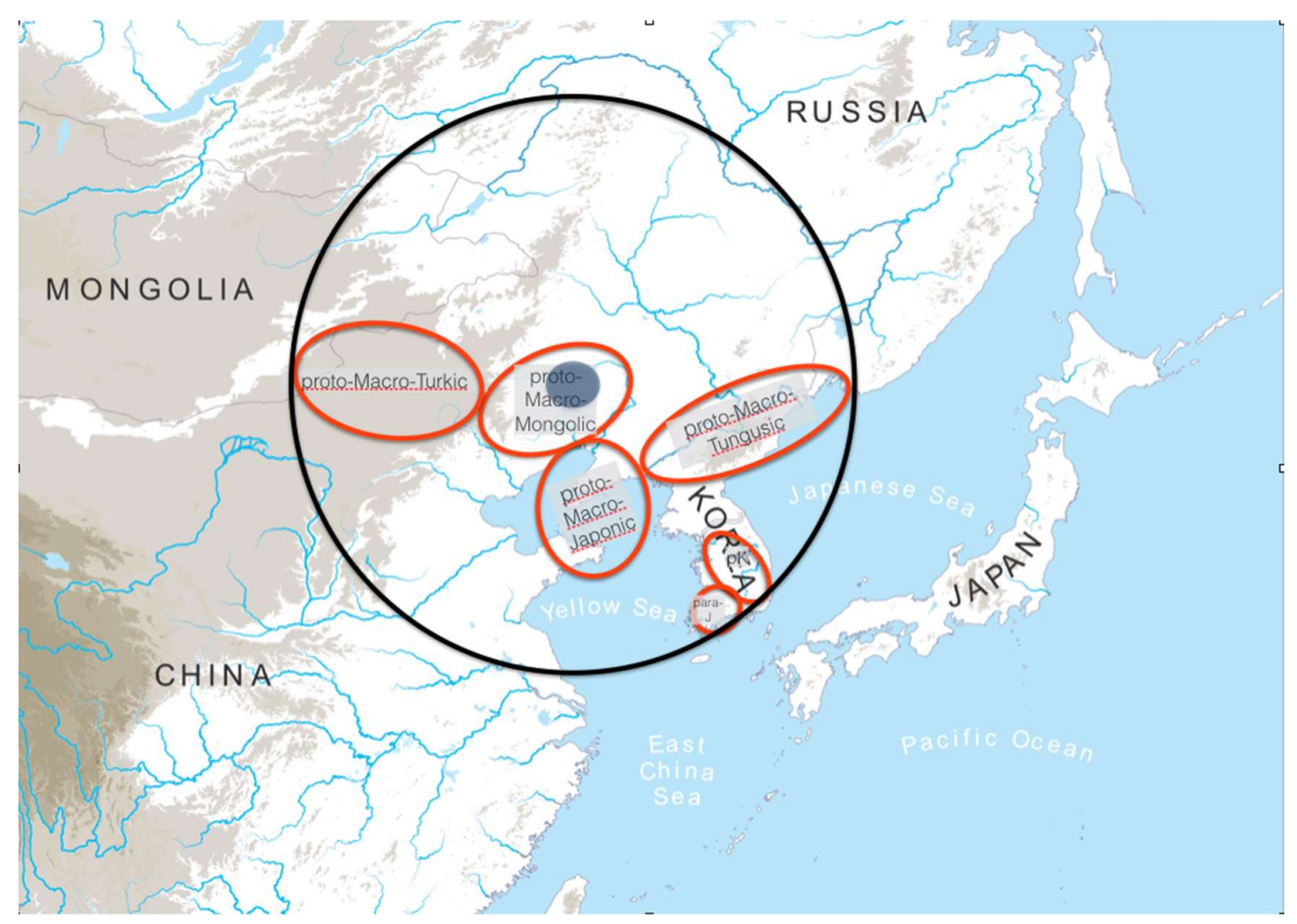

Figure 44.2 The core of the spread zone of the Proto-Macro-Turkic, Proto-MacroMongolic, Proto-Macro-Tungusic, Proto-Macro-Japonic, Para-Japonic and ProtoKoreanic languages at the beginning of the first millennium $\mathrm{BC}$

A location of the original homeland in the West Liao River region is further corroborated by combining the root age of Proto-Transeurasian (see section 44.2.1) with the presence of agricultural and weaving vocabulary in the ancestral language. Across North and East Asia, only the Xinglongwa culture, situated in the West Liao River Region in the 6th millennium BC, answers to these restrictions. 
Given the maritime character of Proto-Japono-Koreanic vocabulary as opposed to the vocabulary reconstructed for Proto-Altaic, it would be plausible to assume a breakaway model, whereby there was geographical continuity between the Transeurasian and Altaic speech communities in the West Liao River region, while the JapanoKoreanic speakers left and settled in coastal areas after their separation. This is supported by the observation that the West Liao River region is in the center of the spread zone of the Proto-Macro-Turkic, Proto-Macro-Mongolic and Proto-MacroTungusic languages and it is also the region representing the greatest linguistic diversity with regard to the deepest subgroups of Altaic, notably pockets of Tungusic and Mongolic languages are present in the area.

\subsubsection{The Proto-Turko-Mongolic homeland}

Given the association of the reconstructed vocabulary of Proto-Tungusic with the natural and cultural context of the region of the southern Primorye (Robbeets et al., this volume: Chapter 43), the most parsimonious hypothesis is a break-away model whereby there is geographical continuity between the Altaic and Turko-Mongolic speech communities, while the Tungusic speakers separated and moved into the Russian Far East. The original location of the Proto-Turko-Mongolic homeland west of the Liao River is also supported by the nearly adjacent location of Proto-MacroTurkic and Proto-Macro-Mongolic on the western and eastern slopes of the Khingan mountain range. 
This is a draft version of a chapter that appears in Robbeets, $M$ and A. Savelyev (eds). The Oxford Guide to the Transeurasian Languages (OUP, 2020)' see https://global.oup.com/academic/product/the-oxford-guide-to-thetranseurasian-languages-9780198804628.

The research leading to these results has received funding from the European Research Council under the Horizon 2020 Program/ ERC Grant Agreement n. 646612 granted to Martine Robbeets.

The cultural vocabulary of Proto-Japano-Koreanic includes maritime vocabulary (Robbeets 2005, 2017a), weaving terminology and agricultural words (Section 44.2.3). In addition to the reconstruction for 'ocean, sea' and 'boat', we find terms for 'crab, Portunus trituberculatus' and 'swellfish, Takifugu chinensis'. These species inhabit the marine waters around China, Korea, and Japan, but are most prevalent in the Bohai Sea. Given the original situation of the Transeurasian homeland in the West Liao River basin, a movement to the coastal area of the Bohai Sea would be conceivable. This location of the Proto-Japano-Koreanic homeland alligns with that proposed by Unger (2014: 224) and Francis-Ratte (2016: 472-473).

Moreover, the reconstruction of Proto-Japano-Koreanic vocabulary dedicated to weaving is in line with archaeological finds of spindle whorls dating back to ca. 3600 BC within the context of the Houwa (4350-2900 BC) and Xiaozhushan (4000-2000 BC) cultures on the Liaodong Pensinsula (Xu 1995: 71, 74). These cultures belonged to the same cultural system and were familiar with millet agriculture (see Section 44.3.2.2).

Given the lack of rice-vocabulary in Proto-Japono-Koreanic (Robbeets et al., this volume: Chapter 43) and its dating to the fourth millennium BC, we can infer that the speech community must have been situated to the north of the cultures on the Yellow River and the Shandong Peninsula that were familiar with both millet and rice agriculture at that time. The original presence of Macro-Japonic in the LiaodongShandong interaction sphere and the northern derivation of Proto-Koreanic indicates the location of the Proto-Japano-Koreanic homeland on the Liaodong Peninsula as the most parsimonious hypothesis. 
This is a draft version of a chapter that appears in Robbeets, M and A. Savelyev (eds). The Oxford Guide to the Transeurasian Languages (OUP, 2020)' see https://global.oup.com/academic/product/the-oxford-guide-to-thetranseurasian-languages-9780198804628.

The research leading to these results has received funding from the European Research Council under the Horizon 2020 Program/ ERC Grant Agreement n. 646612 granted to Martine Robbeets.

\subsubsection{Reconstruction of agricultural vocabulary}

\subsubsection{Proto-Transeurasian}

Table 44.2 enables us to make a number of inferences indicating that the speakers of Proto-Transeurasian were familiar with agriculture. For a detailed explanation of the etymologies in the table, I refer to Robbeets (2017f).

First, etymologies (1) and (2) suggest that the ancestral speakers made an explicit distinction between "field for cultivation" and "uncultivated field". The Turkic word PTk *(p)ati *(p)ata 'irrigated field for cultivation' in (1) can be reconstructed, considering PTk *(p)atï-z 'watered fields' and PTk*(p)ata-g 'island' as reflexes of the same etymon, whereby PTk *-z represents a dual and collective suffix (e.g., in paired body parts such as OT kö-z 'eyes', $t i-z$ 'knees', agï-z 'lips' and $k \ddot{o} k \ddot{u}-z$ 'breasts', ethnonyms such as OT ogu-z and kïrgï-z, sets of more than one such as $i k i-z$

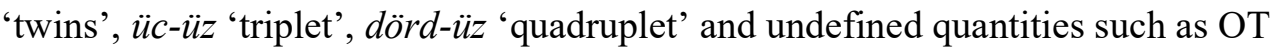
yultu-z 'stars', yïldï-z 'roots') and PTk *-(A)g a petrified place suffix (e.g., PTk *o:t

'fire' $\rightarrow$ o:t-ag 'tent, dwelling place'). For Turkic, it is commonly assumed that word initial PTk * $p$ - developed over a bilabial fricative into $h$-, leaving only a trace in Khalaj $h$ - and finally disappearing in most of the contemporary Turkic languages. There are only a few cases in which Khalaj $h$ - supports the reconstruction and comparison of PTk*p-, e.g. OT adaq, Khalaj hadaq 'foot' < PTk *pada-k (compare K patak, MK pa·tay, pa·twok 'bottom' < *pata-) or OT ör-, Khalaj hör- 'to plait' < PTk *pö:r- (compare Khalkha oro:-, Mgr. furo:-, MMo. hura- < PMo *poro- 'to entwine' and Evk. horol- 'to spin', Ma. foro- 'to turn round' < PTg * poro- 'to spin, weave'). When a Khalaj cognate is missing, we perceive a correspondence between 
This is a draft version of a chapter that appears in Robbeets, M and A. Savelyev (eds). The Oxford Guide to the Transeurasian Languages (OUP, 2020)' see https://global.oup.com/academic/product/the-oxford-guide-to-thetranseurasian-languages-9780198804628.

The research leading to these results has received funding from the European Research Council under the Horizon 2020 Program/ ERC Grant Agreement n. 646612 granted to Martine Robbeets.

initial $\varnothing$ in Turkic and PJ *p-, PK*p-, PTg*p- or PMo*p-, as is the case here. The initial $*(p)$ in the Proto-Turkic reconstruction * $(p)$ atï $\sim(p)$ ata is bracketed because the alleged loss of the initial labial stop * $p$ - cannot be confirmed since we lack a Khalaj cognate.

Second, we reconstructed a Proto-Transeurasian verb 'to sprinkle with the hands, sow' in Table 44.2 (3). Although the meaning 'to sow' is only explicitly attested in the Korean verbs, it can be reconstructed to the ancestral language, given the derived nouns for 'seed, seedling' and 'millet-like crop' in Table 44.2 (4) and (5). Besides, the polysemy may be prototypical for the Transeurasian family because it is recurrent throughout the Transeurasian languages, including verb roots that are not cognate to the root under discussion such as Japanese maku 'to sprinkle, scatter, strew, sow (seed)', hodokosu 'sprinkle, scatter, sow; give, perform, apply', Sibe swata- 'to sprinkle, sow', Turkish sač- 'to sprinkle, scatter, sow (seed)', $e k$ - 'to sprinkle, scatter, drop, throw about, sow (seed)', etc. Therefore, we can argue that the speakers of Transeurasian extended their verb for 'to sprinkle (with the hands)' to 'to sow (seeds)' and were thus becoming familiar with plant cultivation.

Finally, as both the verb base and the instrumental deverbal noun suffixes are shared between the daughter languages in the words for 'seed, seedling' and 'milletlike crop' in Table 44.2 (4) and (5), it is likely that the derivations took already place at the common Proto-Transeurasian stage. The derivation of 'seed' as 'what one uses for sowing' implies that seeds were not merely collected and consumed but planted and used for cultivation. Similarly, the word for a 'millet-like crop such as broomcorn or barnyard millet' is derived as 'what is sown'. This recalls the derivation of Proto- 
This is a draft version of a chapter that appears in Robbeets, M and A. Savelyev (eds). The Oxford Guide to the Transeurasian Languages (OUP, 2020)' see https://global.oup.com/academic/product/the-oxford-guide-to-thetranseurasian-languages-9780198804628.

The research leading to these results has received funding from the European Research Council under the Horizon 2020 Program/ ERC Grant Agreement n. 646612 granted to Martine Robbeets.

Turkic *tarï- 'to cultivate ground' as the deverbal noun tarï-g 'what is cultivated; main crop' (Robbeets et al., this volume: Chapter 43).

Table 44.2 Agricultural vocabulary in Proto-Transeurasian

\begin{tabular}{|c|c|c|}
\hline $\begin{array}{l}\text { Proto- } \\
\text { Transeurasian }\end{array}$ & $\begin{array}{l}\text { Daughter } \\
\text { branches }\end{array}$ & Attested languages \\
\hline $\begin{array}{l}\text { (1) PTEA } \\
\text { *pata } \\
\text { 'field for } \\
\text { cultivation' }\end{array}$ & $\begin{array}{l}\text { PTk*(p)ati } \\
\text { 'delimited field } \\
\text { irrigated for } \\
\text { cultivation' } \\
\left(\mathrm{PTk} *-r_{2}\right. \\
\text { collective suffix) }\end{array}$ & $\begin{array}{l}\text { OTk (Karakhanid) atïz 'any strip of land } \\
\text { between two dikes', atïzla- 'to create irrigation } \\
\text { ditches (for cultivation)', MTk. atïzla- 'to create } \\
\text { an irrigation canal in a field', Uig. etiz 'field, } \\
\text { cornfield; arable land', Tkm. atïz 'furrow; strip } \\
\text { of land', Shor adïz 'a measure for fields, } 1 / 18 \\
\text { dessiatin (= ca. } 607 \text { square meters)', Kirg. adïr } \\
\text { 'hilly terrain, hill ridge, highlands', Kaz. atiz 'a } \\
\text { plot of land, watered by irrigation canals and } \\
\text { properly limited', adïr 'hillock; highlands, hilly } \\
\text { terrain', }\end{array}$ \\
\hline & $\begin{array}{l}\mathrm{PTk} *(p) a t a \\
\text { 'delimited field } \\
\text { irrigated for } \\
\text { cultivation' }\end{array}$ & $\begin{array}{l}\text { MTk. (Middle Kipchak) atov 'island', MTk } \\
\text { (Chagatay) adaq 'island (overgrown with } \\
\text { plants), an island with vegetation', Chu. udă } \\
\text { 'island; a grove in a field; meadow; ravine, }\end{array}$ \\
\hline
\end{tabular}




\begin{tabular}{|c|c|c|}
\hline & $\begin{array}{l}\left(\mathrm{PTk}^{*}-(A) g \text { place }\right. \\
\text { suffix? })\end{array}$ & $\begin{array}{l}\text { valley; locality; site, sector', Tk. ada 'island', } \\
\text { Gag. ada 'cape; island; (rarely) swamp, bog, } \\
\text { marsh', Az. ada 'island', Tkm. a:da 'island', } \\
\text { Karaim ada 'island', Kumyk ataw 'island', Uig. } \\
\text { ata 'island', KKalp. ataw 'island', Bash. ataw } \\
\text { 'island; a clearing in the wood, meadow, } \\
\text { grassplot' }\end{array}$ \\
\hline & $\begin{array}{l}\text { PK *patı } \\
\text { '(dry) field' } \\
(\mathrm{PK} *-(\mathrm{i} / \Lambda) k \text { place } \\
\text { suffix })\end{array}$ & $\begin{array}{l}\text { K path, MK path '(dry) field, farm, patch, } \\
\text { garden, position on a game board' }\end{array}$ \\
\hline & $\begin{array}{l}\text { PJ * pata } \\
\text { '(dry) field' } \\
(\mathrm{PJ} *-k a \text { place } \\
\text { suffix, PJ *-i } \\
\text { substantivizer) }\end{array}$ & $\begin{array}{l}\text { J hata, OJ pata '(dry) field', J hatake, OJ } \\
\text { patake }_{2} \text { 'field, farm, plantation, garden', Shuri } \\
\text { (Okinawa) hataki, Naze (Amami) hatəo, } \\
\text { Ishigaki (Yaeyama) patagi, Oura (Miyako) } \\
\text { patagi, Yonaguni hatagi, PR * patake 'field, } \\
\text { croft' }\end{array}$ \\
\hline $\begin{array}{l}\text { (2) PTEA } \\
{ }^{*} m u d a \\
\text { 'uncultivated }\end{array}$ & $\begin{array}{l}\text { PTg *muda } \\
\text { 'plain, open field, } \\
\text { highland' }\end{array}$ & 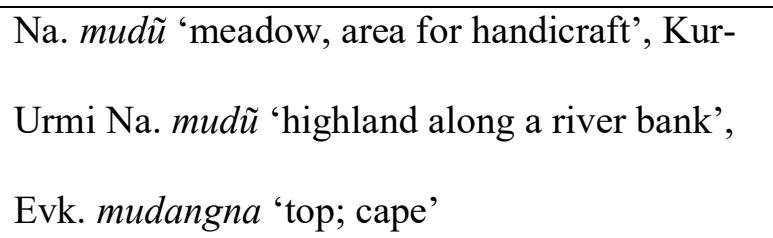 \\
\hline
\end{tabular}


The research leading to these results has received funding from the European Research Council under the Horizon 2020 Program/ ERC Grant Agreement n. 646612 granted to Martine Robbeets.

\begin{tabular}{|c|c|c|}
\hline \multirow[t]{2}{*}{ field' } & $\begin{array}{l}\mathrm{PK}^{*} m u t \wedge-k \text { 'dry } \\
\text { land' } \\
(\mathrm{PK} *-(\dot{\mathrm{i}} / \Lambda) k \text { place } \\
\text { suffix })\end{array}$ & K muth, MK muth 'land, dry land' \\
\hline & $\begin{array}{l}\text { PJ *muta } \\
\text { 'uncultivated } \\
\text { land, marshland' }\end{array}$ & $\begin{array}{l}\text { J (dial.) muta 'swamp, marshland', Miyako } \\
\text { muta 'land', Shodon mutha 'swamp' }\end{array}$ \\
\hline \multirow[t]{3}{*}{$\begin{array}{l}\text { (3) PTEA } \\
\text { * pisi- } \\
\text { 'sprinkle with } \\
\text { the hands, } \\
\text { sow' }\end{array}$} & $\begin{array}{l}\text { PMo } \\
\text { *pesü-r-/*pisü-r- } \\
\text { 'to sprinkle, } \\
\text { scatter; jump } \\
\text { around' } \\
\text { (PMo *-r- } \\
\text { intensive) }\end{array}$ & $\begin{array}{l}\text { Dag. xesere- 'to jump', xasur-, xesura- 'to } \\
\text { sprinkle', Mgr. fizuru- 'to sprinkle, pour, cast } \\
\text { (metal)' }\end{array}$ \\
\hline & $\begin{array}{l}\text { PTg } \\
\text { *pisi- } \\
\text { 'to sprinkle with } \\
\text { the hands' }\end{array}$ & $\begin{array}{l}\text { Ma. fisi- 'to sprinkle with the hands; to shake, } \\
\text { to toss (one's sleeves), Olcha pisuri- 'to } \\
\text { sprinkle', Orok pisitči- 'to sprinkle', Na. pisi-, } \\
\text { fisi- 'to sprinkle' }\end{array}$ \\
\hline & PK & K ppu:li- 'to sprinkle, rain slightly (intr.); to \\
\hline
\end{tabular}




\begin{tabular}{|c|c|c|}
\hline & $\begin{array}{l}\text { *pis- } \\
\text { 'to sprinkle, } \\
\text { scatter, sow' }\end{array}$ & $\begin{array}{l}\text { sprinkle, shower, water (tr.); to scatter, sow', K } \\
\text { ppuli 'a root (of a plant)', MK spu-li- 'to } \\
\text { sprinkle' (MK -(u)li- transitivizer }<\mathrm{PK} * \text {-(u)l- } \\
\text { anticausative + *-i- causative), MK spih- 'to } \\
\text { sprinkle; slander' , K p:al- 'to wash, launder, } \\
\text { wash out (tr.)', MK ·spol- 'to wash (tr.)' (PK *- } \\
\text { (n/i) l- pluractional), MK ·spum- 'sprinkle, } \\
\text { spout, spurt' (PK *-mi- } \sim m \iota-\text { inclinational) }\end{array}$ \\
\hline $\begin{array}{l}\text { (4) PTEA } \\
* \text { pisi- } i \\
\text { (sow- } \\
\text { INS.NMLZ) } \\
\text { 'seed, } \\
\text { seedling' } \\
\text { (PTEA *-i/ø } \\
\text { instrumental } \\
\text { deverbal noun } \\
\text { suffix) }\end{array}$ & $\begin{array}{l}\text { PMo *pesi/*pisi } \\
\text { 'origin or base of } \\
\text { a plant' }\end{array}$ & $\begin{array}{l}\text { MMo. nisi, hesi, Written Mongolian isi esi } \\
\text { 'foundation, basis, origin, source; a stalk of } \\
\text { grain, trunk of a tree, stem of a plant, shoot; } \\
\text { handle, grip', Khal. iš eš '1 source, basis; } 2 \\
\text { stem, stalk, trunk, underground stem; } 3 \text { handle, } \\
\text { shaft'; Bur. eše '1, 2, 3', Kalm. iš 'beginning, } \\
\text { source; stalk (of plant), stem (of tree); handle, } \\
\text { grip', Ordos eši } \sim i s ̌ i ~ ‘ 1,2,3 \text { ', Bao. jeśi, heši } \\
\text { 'handle, grip', Dag. xěs, xeši, heši 'handle, grip, } \\
\text { knob'; Eastern Yugur šs 'handle, stem', } \\
\text { Kangjia heši 'handle, grip' (Nugteren 2011: } \\
\text { 354) }\end{array}$ \\
\hline & $\begin{array}{l}\mathrm{PK} \text { *pisi 'seed; } \\
\text { lineage' }\end{array}$ & $\begin{array}{l}\text { MK ·psi, K ssi 'seed, kernel; lineage, descent, } \\
\text { breed', K pye-psi 'rice seed' }\end{array}$ \\
\hline
\end{tabular}


This is a draft version of a chapter that appears in Robbeets, M and A. Savelyev (eds). The Oxford Guide to the Transeurasian Languages (OUP, 2020)' see https://global.oup.com/academic/product/the-oxford-guide-to-thetranseurasian-languages-9780198804628.

The research leading to these results has received funding from the European Research Council under the Horizon 2020 Program/ ERC Grant Agreement n. 646612 granted to Martine Robbeets.

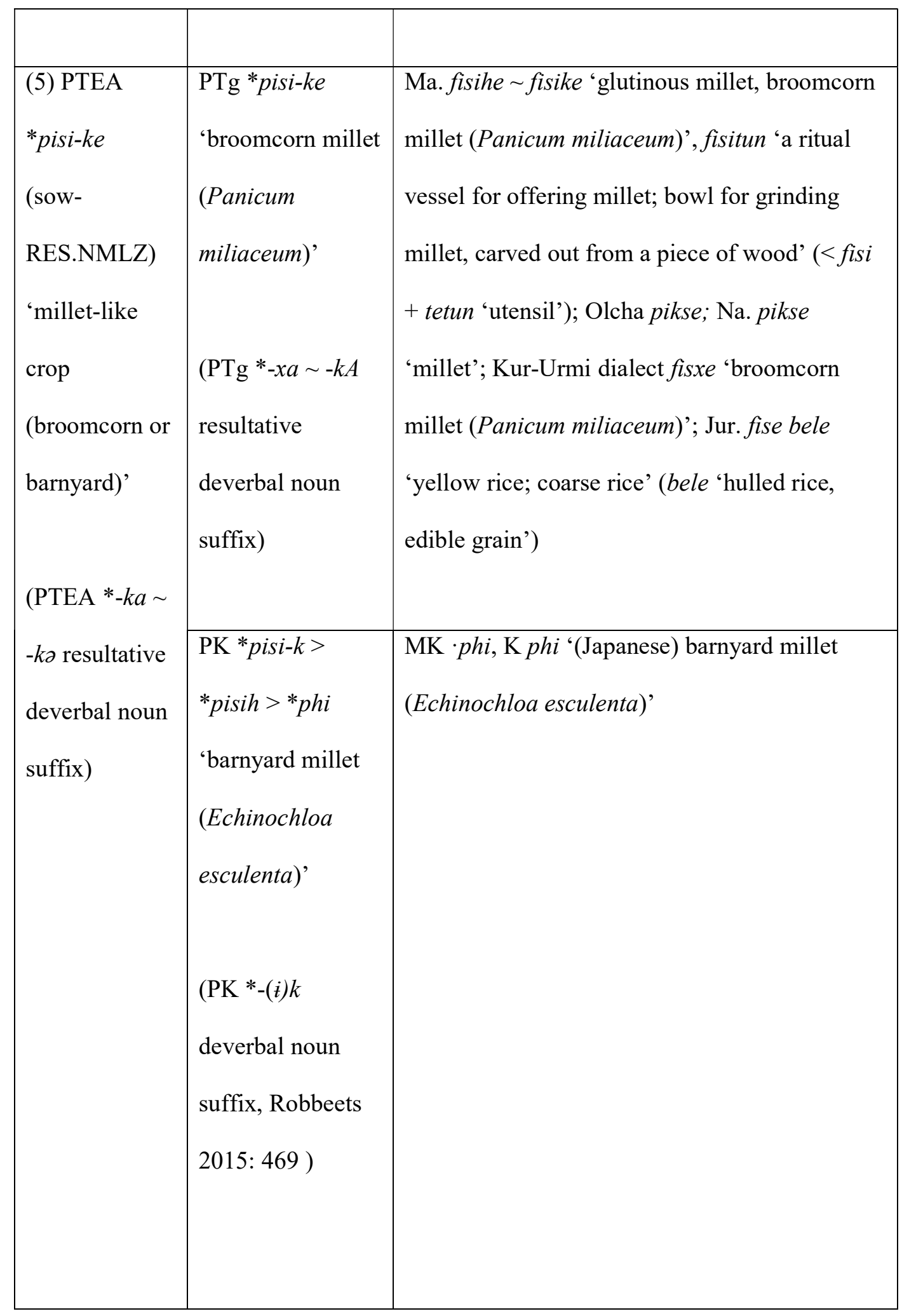




\subsubsection{Proto-Altaic}

If agricultural terms are shared between two or more branches of Altaic, in most cases the words are ultimately derivable from Proto-Transeurasian, as is the case for the etymologies in Table 44.2. There are very few agricultural terms that are uniquely shared by Turkic, Mongolic and Tungusic languages.

One exception is pA *tari- 'to cultivate' in Table 44.3 (1) It should be noted that the Old Turkic form involved means 'to disperse' in addition to 'to cultivate'. Since this meaning is primary in Turkic, while the other Altaic languages only reflect the secondary meaning 'to cultivate', this could be taken as an indication of borrowing. However, the underived verbal nature of the compared roots, the rich distribution of cognates across the Altaic languages and the presence of a potential cognate in Korean argue against a borrowing scenario. There is a parallel in Proto-Korean *til'to cultivate' and its derived noun PK *til-ik 'field-' (PK *-ik deverbal noun suffix, Robbeets 2015: 469 ), which is not included in the table because of the mismatch of the Korean vowel. The verb is reflected in various forms such as $\mathrm{K} k u l w u$ tuli- 'turn over the soil and sow for a second crop' ( $k u l w u$ 'aftercrop'), K tuli- 'to winnow grain from the chaff', K noph-tuli 'an unproductive rice field in a high place with little water' (noph- 'to be high, elevated'), K kiph-tuli 'a low-set rice field' (kiph- 'to be deep'; - $i$ deverbal noun suffix), while the derived noun is found in K tulh, MK tulh / tuluh 'field-, wild'.

In addition to this cultivation verb, Savelyev (2017) finds that many common Altaic agricultural cognates have been lost because they were replaced by or 
semantically recycled as pastoralist terms. For instance, the common Altaic word for 'young male pig' in Table 44.3 (1) has been lexically recycled as 'young camel' or 'young horse' in Turkic. The details of the distinction of 'young male pig' in terms of age and gender indicate the importance of the pig in the subsistence economy.

Domesticated pigs have been recovered from early Neolithic sites in Southern Manchuria (Shelach 2000). They are more typical for an agricultural than a pastoral context.

Table 44.3 Agricultural vocabulary in Proto-Altaic

\begin{tabular}{|c|c|c|}
\hline Proto-Altaic & Daughter branches & Attested languages \\
\hline $\begin{array}{l}\text { (1) } \mathrm{PA} * \text { tari- } \\
\text { 'to cultivate' }\end{array}$ & $\begin{array}{l}\text { PTk *tarï- } \\
\text { 'to scatter, sow, cultivate } \\
\text { (land)' }\end{array}$ & $\begin{array}{l}\text { OTk. tarï- 'to disperse, cultivate (a } \\
\text { field)', MTk. (Chagatay) tar-, tari- 'to } \\
\text { scatter seeds, sow', Kirg. tarï- 'to sow, } \\
\text { cultivate ground, plow', Bash. tarï- 'to } \\
\text { sow', Alt. tarï- 'to sow, cultivate', Uig. } \\
\text { dar-, tar- 'to sow', tarï-, taru- 'to } \\
\text { cultivate ground', S-Yug. tarï- 'to sow'; } \\
\text { Khak. tarï- 'to sow', Tuv. tarï- 'to plow, } \\
\text { cultivate ground, sow, plant'; Tofa. tarï- } \\
\text { 'to sow, plant' }\end{array}$ \\
\hline & $\begin{array}{l}\text { PMo *tari- } \\
\text { 'to sow, plant; to plough' }\end{array}$ & $\begin{array}{l}\text { MMo. tari- 'to sow, plant'; WMo. tari- } \\
\text { 'to sow, plant; to plough; to inoculate } \\
\text { against infection, vaccinate'; Khal. tari- }\end{array}$ \\
\hline
\end{tabular}




\begin{tabular}{|c|c|c|}
\hline & $\begin{array}{l}\text { PTg *tari- } \\
\text { 'to cultivate' }\end{array}$ & $\begin{array}{l}\text { 'to sow; to plant; to infect; to perform a } \\
\text { deed; to inject; to vaccinate'; Ordos tari- } \\
\text { 'to sow; to plant; to plow; to inoculate } \\
\text { (smallpox)'; Bur. tari-; Kalm. tär-; } \\
\text { Eastern Yughur tarə- 'to sow, plant'; } \\
\text { Mgr. tarə- tari- 'to sow; to cultivate } \\
\text { land'; Bao. tarə- tar-; Kgj. tari-; Dgx. } \\
\text { tari- 'to sow, plant' } \\
\text { Evk. tari- tare- tale- 'to sow'; Sol. } \\
\text { tari- 'to sow seeds; to plant; to cultivate; } \\
\text { to grow; to disseminate; to inject; to } \\
\text { infect, to catch a disease', tarigko } \\
\text { 'injector'; Ma. tari- 'to cultivate, farm; } \\
\text { tali 'garden for cultivating plants' } \\
\text { to plow'; Jur. tali- tari- 'to sow, plant, } \\
\text { cultivate'; Ulcha tari- 'to sow, plant'; } \\
\text { Na. tari- 'to sow seeds', tariko 'sowing }\end{array}$ \\
\hline $\begin{array}{l}\text { (2) PA *toru } \\
\text { 'young male } \\
\text { pig' }\end{array}$ & $\begin{array}{l}\text { PTk *to:rum 'young } \\
\text { camel/horse/cattle' }\end{array}$ & $\begin{array}{l}\text { OTk (Karakh.) torum 'young camel, } \\
\text { camel colt', Tk. deve torun, torum (dial.) } \\
\text { 'two-years-old camel', Tkm. to:rum } \\
\text { 'camel colt (between } 6 \text { months and one }\end{array}$ \\
\hline
\end{tabular}




\begin{tabular}{|c|c|}
\hline & $\begin{array}{l}\text { year)', Uigh. topaq-torum 'young cattle' } \\
\text { (topak 'one-year-old calf'), Tuva dorum } \\
\text { 'camel colt (in the second year)', Salar } \\
\text { torï 'foal' }\end{array}$ \\
\hline $\begin{array}{l}\text { PMo *toru 'young/ male } \\
\text { pig' } \\
\text { (PMo *-i animal suffix in } \\
\text { e.g. *gaka-i 'pig', *noka- } \\
i \text { 'dog', *moga-i 'snake') }\end{array}$ & $\begin{array}{l}\text { WMo. torui 'suckling pig', toruyu 'one- } \\
\text { year-old wild boar', Khal. toroy 'piglet; } \\
\text { young of a domestic yak', toru: 'two- } \\
\text { years-old piglet', Bur. toroy 'piglet', } \\
\text { Kalm. torä: 'piglet', Ordos torö: 'young } \\
\text { donkey' }\end{array}$ \\
\hline $\begin{array}{l}\text { PTg *toro-ki: ‘male pig' } \\
\text { (PTg *-ki: animal suffix) }\end{array}$ & $\begin{array}{l}\text { Evk. toroki: 'boar', Neg. toroki: 'boar, } \\
\text { wild boar (Upper dial.)' }\end{array}$ \\
\hline
\end{tabular}

\subsubsection{Proto-Turko-Mongolic}

Given the extensive contact relations in prehistory, it is very difficult to distinguish between borrowing and inheritance for Turko-Mongolic comparative sets that do not have cognates elsewhere in the Transeurasian languages. The bulk of common pastoral vocabulary is the result of borrowing (Savelyev 2017). However, a few terms relating to dairying, including the verb 'to milk' in Table 44.4 go back to a common ancestral term. The common Turko-Mongolic verb for 'to milk' may be cognate with the Japano-Koreanic verb *saka- 'to ferment', reflected in J sake, OJ saka-/ sake 2 ake, 


\section{ted in e with the Japanliquoranic vsakar- 'be at a peak, be in heat', OJ sak- 'bloom'}

and in K sak-, MK sak- 'to ferment, to rot'. The Turkic and Mongolic verbs share a secondary meaning 'to draw tightly towards oneself', which may have developed once at the common Turko-Mongolic level rather than having occurred twice, independently in the two proto-languages. Given the sharing of both primary and secondary semantics, the correspondence between bare verb roots and the cognates in Japanese and Korean, the correlation is unlikely to be the result of borrowing.

Table 44.4 Milking in Proto-Turko-Mongolic.

\begin{tabular}{|c|c|c|}
\hline $\begin{array}{l}\text { Proto-Turko- } \\
\text { Mongolic }\end{array}$ & Daughter branches & Attested languages \\
\hline $\begin{array}{l}\text { PTMo *saga- } \\
\text { 'to milk, to draw } \\
\text { towards oneself' }\end{array}$ & $\begin{array}{l}\text { PTk * sag- 'to milk; } \\
\text { 'to draw towards } \\
\text { oneself; to pull out; } \\
\text { to pull off' }\end{array}$ & $\begin{array}{l}\text { OTk say- 'to milk (an animal)', OTk } \\
\text { (Karakh.) say-, Chu. su-, dial. sawv- 'to } \\
\text { milk; to grind brick into powder', Tk. } \\
\text { say- 'to milk; to fleece, despoil; to } \\
\text { extract honey from the hive; to pour } \\
\text { out rain (cloud); to unwind'; sayïm } \\
\text { 'milking; quantity of milk taken at one } \\
\text { time, quantity of honey taken at one } \\
\text { time; milk-giving animal'; sayli 'kept } \\
\text { for milking'; saylik 'dairy animal', } \\
\text { sagmal 'milk, kept for milking, milk- } \\
\text { giving; fit to be fleeced (person)', Gag. }\end{array}$ \\
\hline
\end{tabular}




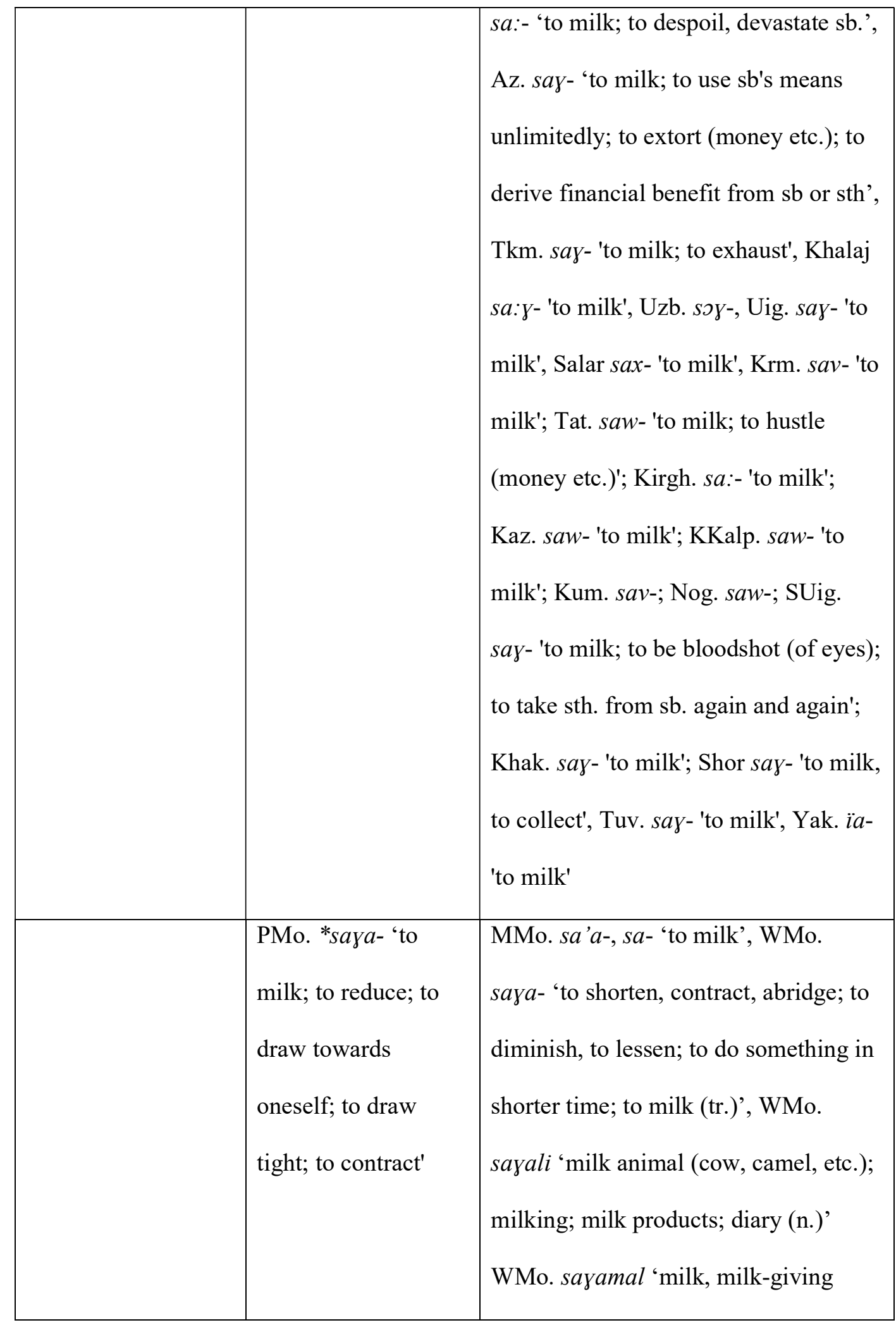




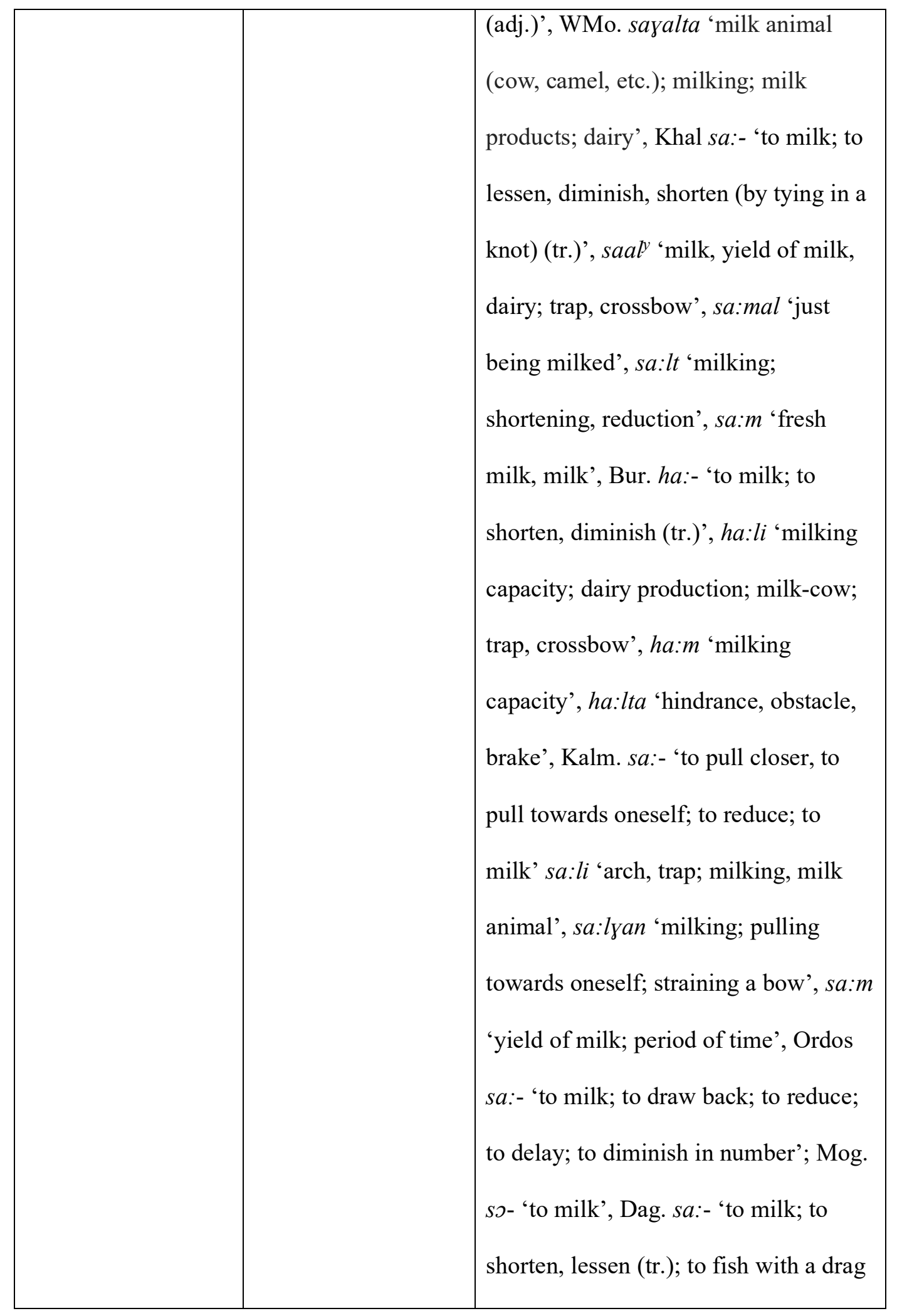




\begin{tabular}{|l|l|}
\hline & $\begin{array}{l}\text { seine', Dgx. } s a \text { - 'to milk'; Bao. } s a:- \text { 'to } \\
\text { milk'; S.-Yugh. sa:- 'to milk'; Mgr. } \\
s(u) a \text { :- 'to milk', sa:li 'milk animal, } \\
\text { female (goat, sheep)' }\end{array}$ \\
\hline
\end{tabular}

\subsubsection{Proto-Japano-Koreanic}

In contrast to the subsistence vocabulary reconstructed for Proto-Transeurasian, the

Proto-Japono-Koreanic lexicon includes maritime terms. However, a specific

vocabulary dedicated to rice cultivation is still lacking. As the agricultural vocabulary

shared between Japonic and Koreanic is rather extensive, I have restricted the items

listed in Table 44.5 to different reconstructions for the term for 'field' in Proto-

Japano-Koreanic. The differentiation between at least five distinct terms for 'field for

cultivation', 'uncultivated field' and 'delimited plot for agriculture' suggests that

agriculture played a central role in the subsistence of the speakers of Proto-Japono-

Koreanic.

Although Transeurasian agricultural vocabulary is often lost in Turkic or Mongolic languages, it is rather well preserved in Japonic and Koreanic languages; in Table 44.5, etymologies (1) and (2) have a probable Transeurasian origin. The higher retention rate can be explained by the fact that Mongolic and Turkic speakers lost agricultural terms when they adopted pastoralism, while Japonic and Koreanic people continued to rely on agriculture, even if they diversified their individual crop packages in the course of history. 
The solid distribution of the Ryukyuan cognates in the etymologies in Table 44.5 reduces the probability that the agricultural terms were borrowed from Old Korean at a time when Mainland Japanese had already separated from the Ryukyuan languages (see Robbeets, this volume: Chapter 36).

Table 44.5 Different terms for 'field' in Proto-Japano-Koreanic

\begin{tabular}{|c|c|c|}
\hline $\begin{array}{l}\text { Proto-Japano- } \\
\text { Koreanic }\end{array}$ & Daughter branches & Attested languages \\
\hline $\begin{array}{l}\text { (1) PJK * pata } \\
\text { 'dry field' } \\
<\text { PTEA *pata } \\
\text { 'field for } \\
\text { cultivation' } \\
\text { see Table 44.1(1) }\end{array}$ & $\begin{array}{l}\text { PJ *pata } \\
\text { '(dry) field' } \\
(\mathrm{PJ} *-k a \text { place suffix, } \\
*-i \text { substantivizer })\end{array}$ & $\begin{array}{l}\text { J hata, OJ pata '(dry) field', J hatake, } \\
\text { OJ patake } 2 \text { 'field, farm, plantation, }_{\text {garden', Shuri (Okinawa) hataki, }} \\
\text { Naze (Amami) hatəo, Ishigaki } \\
\text { (Yaeyama) patagi, Oura (Miyako) } \\
\text { patagi, Yonaguni hatagi, PR *patake } \\
\text { 'field, croft' }\end{array}$ \\
\hline $\begin{array}{l}\text { (2) PJK *muta } \\
\text { 'uncultivated } \\
\text { land' }\end{array}$ & $\begin{array}{l}\text { PK*mutı- } k \text { 'dry land' } \\
(\mathrm{PK} *-(\mathrm{i} / \Lambda) k \text { place suffix })\end{array}$ & K muth, MK muth 'land, dry land' \\
\hline
\end{tabular}


This is a draft version of a chapter that appears in Robbeets, M and A. Savelyev (eds). The Oxford Guide to the Transeurasian Languages (OUP, 2020)' see https://global.oup.com/academic/product/the-oxford-guide-to-thetranseurasian-languages-9780198804628.

The research leading to these results has received funding from the European Research Council under the Horizon 2020 Program/ ERC Grant Agreement n. 646612 granted to Martine Robbeets.

\begin{tabular}{|c|c|c|}
\hline $\begin{array}{l}<\text { PTEA *muda } \\
\text { 'uncultivated } \\
\text { land' } \\
\text { see Table 44.1(2) }\end{array}$ & $\begin{array}{l}\text { PJ *muta } \\
\text { 'uncultivated land, } \\
\text { marshland' }\end{array}$ & $\begin{array}{l}\text { J (dial.) muta 'swamp, marshland', } \\
\text { Miyako muta 'land', Shodon mutha } \\
\text { 'swamp' }\end{array}$ \\
\hline \multirow[t]{2}{*}{$\begin{array}{l}\text { (3) PJK *no } \\
\text { 'field' }\end{array}$} & $\begin{array}{l}\text { PK *non } \\
\text { 'rice paddy field' }\end{array}$ & $\begin{array}{l}\text { K non kali 'plowing a rice field', MK } \\
\text { 'nwon 'paddy field' }\end{array}$ \\
\hline & $\begin{array}{l}\text { PJ *no } \\
\text { 'field' }\end{array}$ & $\begin{array}{l}\text { J no, OJ nol, Hirara (Miyako) nu:, } \\
\text { Ishigaki (Yaeyama) nu:, Yonaguni } \\
n u: \text { 'field' }\end{array}$ \\
\hline \multirow[t]{2}{*}{$\begin{array}{l}\text { (4) PJK * mati } \\
\text { 'delimited plot } \\
\text { for cultivation' }\end{array}$} & $\begin{array}{l}\mathrm{PK} * \text { mat }(i)-k \\
\text { 'delimited plot for } \\
\text { cultivation' } \\
(\mathrm{PK} * \text {-(i/ } / \Lambda) k \text { place suffix })\end{array}$ & $\begin{array}{l}\text { K math 'yard', MK math 'yard, plot } \\
\text { of land for agriculture' }\end{array}$ \\
\hline & $\begin{array}{l}\mathrm{PJ} * \text { mati } \\
\text { 'delimited plot for } \\
\text { cultivation' }\end{array}$ & $\begin{array}{l}\text { J mati 'field (sector/measure), } \\
\text { quarters, town, market', OJ mati } \\
\text { 'garden, plot of land for agricultural } \\
\text { proposes' }\end{array}$ \\
\hline
\end{tabular}




\subsection{Triangulation}

\subsubsection{Genetics}

The key objective of the so-called "triangulation" approach is to integrate linguistic inferences with evidence from archaeology and genetics in a single perspective on human prehistory. In the next chapter, Jeong et al. shed light on the genetic relationship of Altaic, Japano-Koreanic and Transeurasian populations.

In spite of the increasing admixture of Mongolic and Turkic-speaking populations with people of Western Eurasian ancestry from the first millennium BC onwards, they find that Altaic populations share a part of their ancestry, which predates gene flows from non-Altaic neighbors. They suggest that the Tungusic populations are the best contemporary proxy of this shared pre-admixture substratum among the Altaic populations, which I named "Ancient North East Asian Ancestry” (ANEA) and marked in pink in Figure 44.3. Recent studies of ancient genomes confirm their findings (Siska et al. 2017; Ning et al. forthcoming.). These studies indicate that the Ancient North East Asian gene pool occupied the region between the Baikal and Russian Far East in the period between roughly 14000 BC and 5000 BC. Surprisingly, the populations of Ancient North East Asian ancestry were genetically different from the populations of Ancestral North West Eurasian ancestry that until the Bronze Age, more precisely around 1500-800 BC, occupied regions as far east as the Khövsgöl area (Jeong et al. 2018a).

Jeong et al. (this volume: Chapter 45) further find that present-day Tungusicspeaking populations, such as the Ulchi, Negidal and Nanai in the lower Amur River basin and the Nivkh-speaking populations on the nearby island of Sakhalin, both are 
genetically continuous with individuals of the Neolithic Boisman culture (4825-2470

BC) in the Russian Far East. Thus, already in the fifth millennium BC, the genetic ancestors of Tungusic and Nivkh-speaking populations lived in the southern

Primorye. In sum, the genetic findings fit with a scenario that a population of Ancient North East Asian ancestry around 6000 BC or earlier originated in Northeast China, expanded westwards, from around $1000 \mathrm{BC}$ onwards, into present-day Mongolia and, gave rise to the contemporary Turkic and Mongolic-speaking populations by mixing with local populations in Mongolia and the Altai-Sayan region.

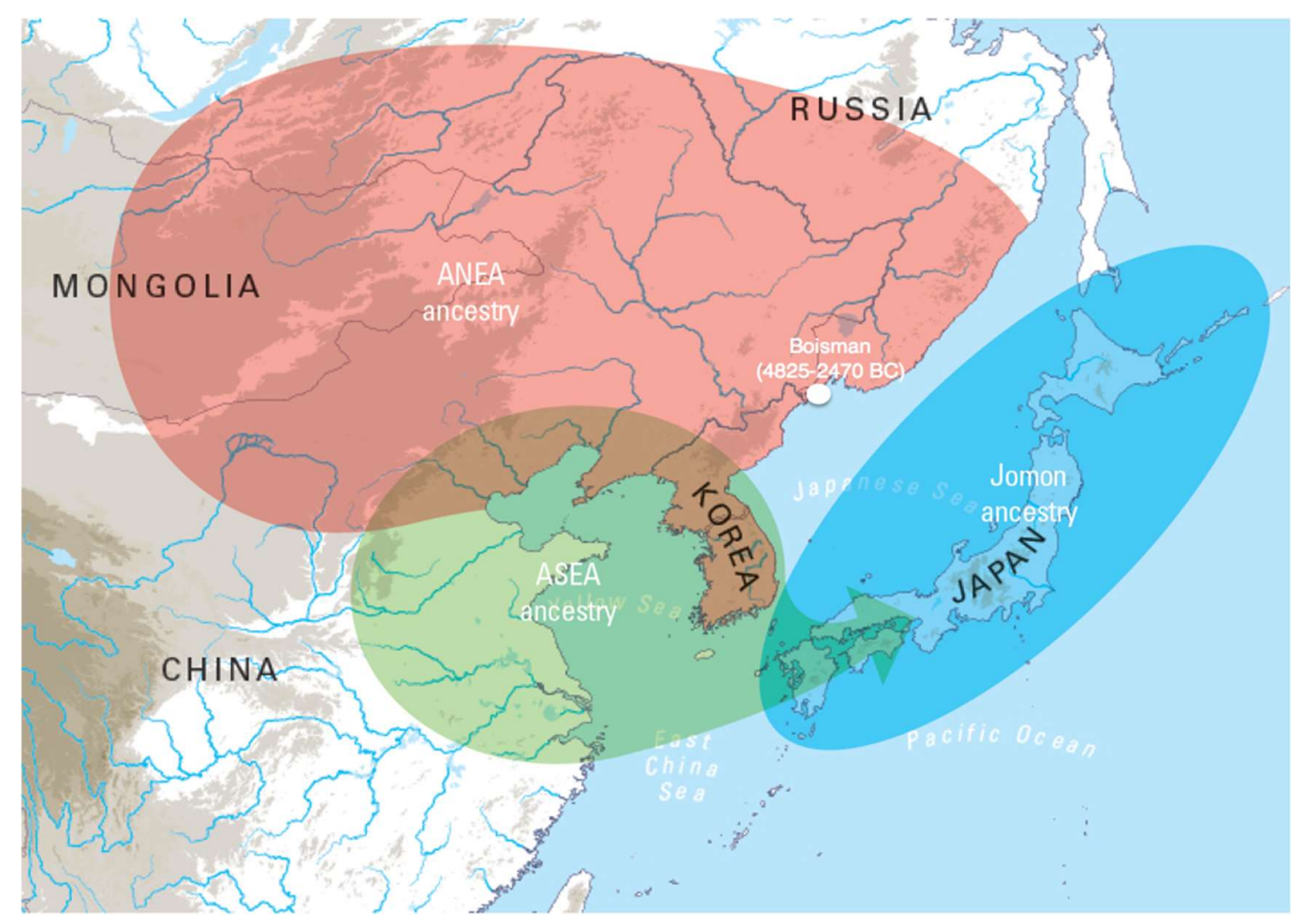

Figure 44.3 The location and admixture of Ancient North East Asian, Ancient South

East Asian and Jomon gene pools in Neolithic population history 
This is a draft version of a chapter that appears in Robbeets, M and A. Savelyev (eds). The Oxford Guide to the Transeurasian Languages (OUP, 2020)' see https://global.oup.com/academic/product/the-oxford-guide-to-thetranseurasian-languages-9780198804628.

The research leading to these results has received funding from the European Research Council under the Horizon 2020 Program/ ERC Grant Agreement n. 646612 granted to Martine Robbeets.

It is generally agreed that Japanese-speaking populations are a mixture of indigenous Jomon (16500-900 BC) hunter-gatherers and incoming Yayoi (900 BC-300 AD)

farmers. The farmers, who arrived on Kyushu Island via the Korean Peninsula, were of Ancient South East Asian related ancestries, indicated in green in Figure 44.3. The exact origin of the underlying Jomon gene pool (blue in Figure 44.3) is still unclear, although it certainly has continuity with contemporary Ainu (Jeong et al. 2016a). Studies of Y-chromosomal DNA estimate that the most recent common ancestor of Japanese and Korean populations existed between 1900 and 2500 BC (Poznik et al. 2016).

Finally, Jeong et al. (this volume: Chapter 45) find that contemporary Tungusic speakers and their Boisman predecessors are genetically closer to modern Koreans and Japanese than to Han Chinese or other southern Chinese populations. This suggests that a part of the Korean and Japanese genomes traces its ancestry back to early Neolithic populations of Ancient North East Asian ancestry and indicates a genetic link between Altaic-speaking and Japano-Koreanic-speaking populations.

\subsubsection{Archaeology}

44.3.2.1 The origins of millet agriculture in the West Liao River Basin As discussed by Li (this volume: Chapter 46), millet cultivation originated in the Xinglongwa culture (6200-5400 BC), one of the earliest farming cultures in Northeast China. There is early evidence for the cultivation of millets, notably large quantities of broomcorn millet (Panicum miliaceum) and small amounts of foxtail millet (Setaria Italica) (Zhao 2011: 301). The cultivation tradition was continuous with the ensuing Zhaobaogu (5400-4500 BC) and Hongshan cultures (4500-2900 
This is a draft version of a chapter that appears in Robbeets, M and A. Savelyev (eds). The Oxford Guide to the Transeurasian Languages (OUP, 2020)' see https://global.oup.com/academic/product/the-oxford-guide-to-thetranseurasian-languages-9780198804628.

The research leading to these results has received funding from the European Research Council under the Horizon 2020 Program/ ERC Grant Agreement n. 646612 granted to Martine Robbeets.

BC). In contrast to the millet-focused subsistence in the Yellow River Region, the Xinglongwa people in the West Liao River Region subsisted on a broad-spectrum strategy, using various wild and cultivated plants, including roots, beans, and nuts (Shelach 2000; Hunt et al. 2008; Weber and Fuller 2008; Zhao 2011; Liu et al. 2012; Liu et al. 2016). The environmental conditions in the West Liao River region are extremely vulnerable to climatic changes. The strengthening of monsoon around 6200 $\mathrm{BC}$ increased precipitation and contracted dune fields, facilitating cultivation and leading to the expansion of early Neolithic cultures such as Xinglongwa and Zhaobaogou (Jia et al. 2017).

\subsubsection{The eastward spread of millet agriculture}

By the time of the Hongshan culture (4500-2900 BC), millet agriculture diffused eastwards, over the Liaodong peninsula to the Korean peninsula and to the Southern Primorye. There is evidence for millet agriculture within the context of the Houwa (4350-2900 BC) and Xiaozhushan (4000-2000 BC) cultures on the Liaodong Pensinsula. Even if millet remains did not appear until around $3000 \mathrm{BC}$ in sites of the Xiazhushan culture (Lee 2016: 404), the presence of agricultural tools in the Houwa cultures indicates that already in the fourth millennium BC, agriculture provided the subsistence base along with hunting and fishing (Xu 1995: 70, 74). Although the remains of the Houwa and Xiaozhushan cultures suggest that they belong to one cultural system different from the Hongshan culture, there are important parallels between pottery patterns, painted vessels and microliths that suggest that the Hongshan culture influenced the cultures on Liaodong. 
This is a draft version of a chapter that appears in Robbeets, M and A. Savelyev (eds). The Oxford Guide to the Transeurasian Languages (OUP, 2020)' see https://global.oup.com/academic/product/the-oxford-guide-to-thetranseurasian-languages-9780198804628.

The research leading to these results has received funding from the European Research Council under the Horizon 2020 Program/ ERC Grant Agreement n. 646612 granted to Martine Robbeets.

From the Liaodong peninsula, millet agriculture spread overland to the Korean peninsula in the fourth millennium BC (Ahn 2010; Ahn et al. 2015: 2; Crawford and Lee 2003: 2; Lee 2011). Systematic archaeobotanical study is lacking for northern Korea, but the earliest appearance of domesticated foxtail and broomcorn millet in southern Korea is dated to the Middle Chulmun period, around 3500 BC (Lee 2011: 307). Xu (1995) sees a connection between Korean Chulmun pottery and the straightsided incised jars of Liaodong.

Finally, around $3300 \mathrm{BC}$ millet agriculture dispersed from its center in the West Liao River basin to the present-day border with Northern Korea and the Southern Primorye, where it gave rise to the Zaisanovskaya culture (3300-1300 BC) (Sergusheva and Vostretsov 2009; Kuzmin 2013). Around 2800 BC, climate change affected the maritime-adapted cultural complexes of the Primorye's coast, through cooling and a fall in sea level, which disrupted the traditional subsistence base of local hunters and fishermen. By consequence, the millet farming of the incoming Zaisanovskaya culture gradually complemented the hunting and fishing of the local Boisman culture (4825-2470 BC) (Vostretsov 2006).

44.3.2.3 The integration of rice and millet agriculture

After $3000 \mathrm{BC}$, rice was added to the agricultural package in the Liaodong-Shandong interaction zone. According to Kim (2003), the millet cultivators on the Korean peninsula had returned to nomadic hunting-gathering by the second millennium $\mathrm{BC}$, perhaps due to another wave of climatic cooling. Archaeobotanical studies such as Miyamoto (2009) and Ahn (2010) show that wet-rice agriculture came to the Korean peninsula in the late second millennium BC (1300-1000 BC) via the Shandong and 
Liaodong peninsulas; see Robbeets et al., this volume: Chapter 43. In the first millennium BC, the rice and millet farmers arrived via the Korean Peninsula in Japan, where they established the Yayoi culture (900 BC-300 AD) (Crawford and Shen 1998; Crawford and Lee 2003).

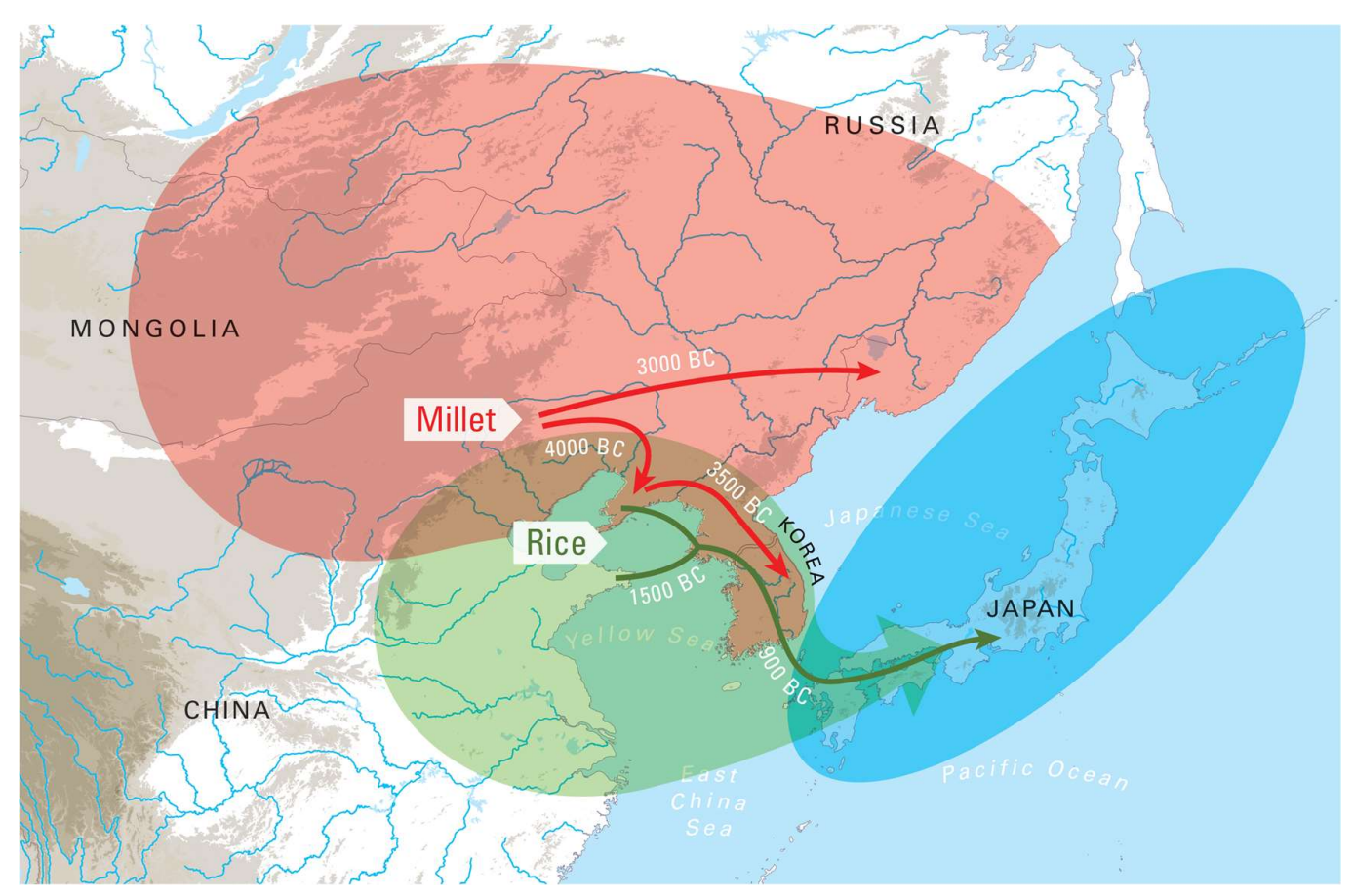

Figure 44.4 The spread of millet and rice agriculture across Northeast Asia

44.3.3 Mapping the three lines of evidence

In this chapter, I reviewed the linguistic, archaeological and genetic evidence with regard to the spread of language, agriculture and genes in the North East Asian Neolithic and Bronze Age. In order to avoid circularity in the argumentation, each line of evidence was based on independent research by specialists in the individual 
This is a draft version of a chapter that appears in Robbeets, M and A. Savelyev (eds). The Oxford Guide to the Transeurasian Languages (OUP, 2020)' see https://global.oup.com/academic/product/the-oxford-guide-to-thetranseurasian-languages-9780198804628.

The research leading to these results has received funding from the European Research Council under the Horizon 2020 Program/ ERC Grant Agreement n. 646612 granted to Martine Robbeets.

fields, in the sense that it did not rely on input from the other disciplines. Table 44.6 integrates the information with regard to 3 variables, i.e. entity, location and estimated time depth, retrieved from the three disciplines, i.e. linguistics, archaeology and genetics for different speech communities, agricultural societies and populations in the North East Asian Neolithic and Bronze Age. The linguistic dating is mainly based on the values inferred by Bayesian inference, but as indicated in Section 44.2.1, these values fall well within the range of the time estimates proposed by other methods.

Table 44.6 suggests a correlation in the location and time depth between the different ancestral speech communities, agricultural societies and gene pools in the region. The genetic finding that the origin of the ANEA lineage was situated in the region from Baikal to Russian Far East before 5000 BC is compatible with the archaeological origins of millet cultivation and the linguistic origins of the Transeurasian family in the West Liao River region around the same time. The primary split between Altaic and Japano-Koreanic in the linguistic family finds a correlate in the earliest dispersal of millet cultivation eastward to the Liaodong Peninsula in the fifth millennium BC. There is a correlation in space and time between the Altaic speech community continuing in the West Liao River region and the Japano-Koreanic community moving to Liaodong on the one hand, and the dispersal of millet agriculture from the Early Hongshan to the Houwa and Xiaozhushan cultures on the other.

The linguistic separation of Tungusic from Turko-Mongolic and its subsequent dispersal to the Amur-Sungari-Ussuri Basin is mirrored by the dispersal of millet agriculture to the region around $3000 \mathrm{BC}$. Interestingly, geneticists confirm that contemporary Tungusic and Nivkh speakers are genetically continuous with 
This is a draft version of a chapter that appears in Robbeets, M and A. Savelyev (eds). The Oxford Guide to the Transeurasian Languages (OUP, 2020)' see https://global.oup.com/academic/product/the-oxford-guide-to-thetranseurasian-languages-9780198804628.

The research leading to these results has received funding from the European Research Council under the Horizon 2020 Program/ ERC Grant Agreement n. 646612 granted to Martine Robbeets.

prehistoric populations in the Amur-Sungari-Ussuri Basin. This observation suggests that the ancestral speakers of Nivkh shifted to the Tungusic language of the incoming farmers (see Robbeets et al. 2017). Unfortunately, however, even if a migration of farmers to this region indeed occurred, geneticists cannot estimate the corresponding admixture time. The reason is that the assumed admixture occurred between two populations of ANEA ancestry, and that - comparable to mixing white paint with white paint — the different genetic components can thus not be distinguished.

Similarly, geneticists posit that people on the Korean peninsula originally were of ANEA ancestry, before the arrival of ASEA ancestry. The archaeological evidence suggests that millet agriculture was transmitted from the Liaodong area to the Korean Penisula around $3500 \mathrm{BC}$, which approximates the estimate of the time of separation between Koreanic and Japonic in the early third millennium BC suggested by some linguistic dating methods but is much earlier than the estimate of $1900 \mathrm{BC}$ by Bayesian methods. It would be reasonable to assume that the admixture of incoming farmers and local hunter-gatherers led to an admixture between ANEA and ANEA genes. Unfortunately, here too, the genetic admixture time cannot be distinguished. Nevertheless, the genetic dating of the most recent common ancestor of Korean and Japanese populations between $2500-1900$ BC seems to predate the arrival of the ParaJaponic rice farmers on the Korean Peninsula and might therefore refer to the original Japano-Koreanic unity on the Liaodong Peninsula.

Finally, geneticists anticipate a large-scale genetic turn over from ANEA to ASEA ancestry on the Korean peninsula and they agree that on the Japanese Islands Jomon genes admixed with incoming ASEA genes. The genetic picture matches the dispersal route of rice agriculture from the Shandong-Liadong area over the Korean Peninsula 
to the Japanese Islands, respectively dated to $1500 \mathrm{BC}$ and $900 \mathrm{BC}$ by archaeologists.

It is also in agreement with the linguistic scenario, whereby Para-Japonic speakers arrived in Korea around $1500 \mathrm{BC}$ and then moved to the Japanese Islands after 900 BC.

Table 44.6 Triangulation of linguistic, archaeological and genetic evidence with regard to the spread of language, agriculture and genes in Northeast Asia in the Neolithic and Bronze Age

\begin{tabular}{|c|c|c|c|}
\hline Variables & Linguistics & Archaeology & Genetics \\
\hline Original entity & Proto-Transeurasian & $\begin{array}{l}\text { Xinglongwa } \\
\text { Zhaobaogu }\end{array}$ & ANEA ancestry \\
\hline Location & $\begin{array}{l}\text { West Liao River } \\
\text { Basin }\end{array}$ & $\begin{array}{l}\text { West Liao River } \\
\text { Basin }\end{array}$ & $\begin{array}{l}\text { Baikal to Russian Far } \\
\text { East }\end{array}$ \\
\hline Estimated time & pre-4700 BC & $\begin{array}{l}6200-5400 \mathrm{BC} \\
5400-4500 \mathrm{BC}\end{array}$ & pre-5000 BC \\
\hline Entity 2 & Proto-Altaic & Hongshan & \\
\hline Location & $\begin{array}{l}\text { West Liao River } \\
\text { Basin }\end{array}$ & $\begin{array}{l}\text { West Liao River } \\
\text { Basin }\end{array}$ & \\
\hline Estimated time & $4700-3293 \mathrm{BC}$ & $4500-2900 \mathrm{BC}$ & \\
\hline Entity 3 & Proto-Tungusic & $\begin{array}{l}\text { Zaisanovskaya to } \\
\text { Krounovskaya }\end{array}$ & $\begin{array}{l}\text { ANEA + ANEA } \\
\text { ancestry? }\end{array}$ \\
\hline Location & Amur-Sungari- & Amur-Sungari- & Amur-Sungari-Ussuri \\
\hline
\end{tabular}


This is a draft version of a chapter that appears in Robbeets, M and A. Savelyev (eds). The Oxford Guide to the Transeurasian Languages (OUP, 2020)' see https://global.oup.com/academic/product/the-oxford-guide-to-thetranseurasian-languages-9780198804628.

The research leading to these results has received funding from the European Research Council under the Horizon 2020 Program/ ERC Grant Agreement n. 646612 granted to Martine Robbeets.

\begin{tabular}{|c|c|c|c|}
\hline & Ussuri Basin & Ussuri Basin & Basin \\
\hline Estimated time & $3293 \mathrm{BC}-200 \mathrm{AD}$ & $3300 \mathrm{BC}-200 \mathrm{AD}$ & $\begin{array}{l}\text { admixture time } \\
\text { undistinguishable }\end{array}$ \\
\hline Entity 4 & $\begin{array}{l}\text { Proto-Turko- } \\
\text { Mongolic }\end{array}$ & $\begin{array}{l}\text { Hongshan } \\
\text { Xiaoheyan }\end{array}$ & \\
\hline Location & $\begin{array}{l}\text { West Liao River } \\
\text { Basin }\end{array}$ & $\begin{array}{l}\text { West Liao River } \\
\text { Basin }\end{array}$ & \\
\hline Estimated time & $3293 \mathrm{BC}-1552 \mathrm{BC}$ & $\begin{array}{l}4500-2900 \mathrm{BC} \\
2900-1600 \mathrm{BC}\end{array}$ & \\
\hline Entity 5 & $\begin{array}{l}\text { Proto-Japono- } \\
\text { Koreanic }\end{array}$ & $\begin{array}{l}\text { Houwa and } \\
\text { Xiaozhushan }\end{array}$ & \\
\hline Location & Liaodong Peninsula & Liaodong Peninsula & \\
\hline Estimated time & $4700-1850 \mathrm{BC}$ & $4350-2000 \mathrm{BC}$ & $2500-1900 \mathrm{BC}$ \\
\hline Entity 6 & Proto-Koreanic & $\begin{array}{l}\text { Middle-Late } \\
\text { Chulmun } \\
\text { Mumun }\end{array}$ & $\begin{array}{l}\text { ANEA + ANEA } \\
\text { ancestry? } \\
\text { ANEA + ASEA } \\
\text { ancestry }\end{array}$ \\
\hline Location & Korean Peninsula & Korean Peninsula & Korean Peninsula \\
\hline Estimated time & $3300 \mathrm{BC}-0 \mathrm{AD}$ & $\begin{array}{l}3500-1500 \mathrm{BC} \\
1500 \mathrm{BC}-300 \mathrm{BC}\end{array}$ & $\begin{array}{l}\text { ANEA + ANEA } \\
\text { admixture time } \\
\text { undistinguishable }\end{array}$ \\
\hline Entity 7 & Proto-Japonic & Yayoi & Jomon + ANEA + \\
\hline
\end{tabular}


This is a draft version of a chapter that appears in Robbeets, $M$ and A. Savelyev (eds). The Oxford Guide to the Transeurasian Languages (OUP, 2020)' see https://global.oup.com/academic/product/the-oxford-guide-to-thetranseurasian-languages-9780198804628.

The research leading to these results has received funding from the European Research Council under the Horizon 2020 Program/ ERC Grant Agreement n. 646612 granted to Martine Robbeets.

\begin{tabular}{|l|l|l|l|}
\hline & & & ASEA ancestry \\
\hline Location & Liaodong/Shandong & Japanese Islands & Liaodong/Shandong \\
to Korea to Japan & & to Korea to Japan \\
\hline Estimated time & $3300-200$ BC & $900 \mathrm{BC}-300 \mathrm{AD}$ & $?$ \\
\hline
\end{tabular}

\subsection{Conclusion}

The Farming Language Dispersal Hypothesis makes the radical and controversial claim that many of the world's major language families owe their present-day distribution to the adoption of agriculture by their early speakers. This view has been seriously called into question, especially for the regions currently occupied by Turkic, Mongolic and Tungusic languages, where farming is often unviable (Heggarty and Beresford-Jones 2014: 4). The traditional hypothesis for the spread of the Transeurasian family is a "Pastoralist Hypothesis", which identifies the primary dispersals of the Transeurasian languages with nomadic expansions starting around 2000 BC in the eastern Steppe.

In the linguistic part of this chapter, I challenged the traditional claim by showing that the homeland, time depth and subsistence vocabulary of Proto-Transeurasian and its primary nodes are incompatible with a Pastoralist Hypothesis, but consistent with the view that the dispersal of the Transeurasian languages is driven by agriculture. Regardless of the current location of the Turkic, Mongolic and Tungusic languages, the homelands of these languages along with those of their common ancestral stages can be situated in regions that are regarded as centers of farming during the Neolithic and Bronze Age. 
In the interdisciplinary part of the chapter, I "triangulated" the linguistic inferences with evidence from archaeology and genetics. The information retrieved from the three disciplines traces the Transeurasian linguistic origins back to the beginnings of agriculture and to the early days of the Ancient North East Asian gene pool in Neolithic North East Asia. It further reveals a sequence of expansions that can be linked to the spread of millet and rice agriculture and to the dispersal of the Ancient North and South East Asian gene pool in this region. Therefore, I propose to add the Transeurasian family to the list of language families worldwide whose dispersal histories are consistent with the Farming Language Dispersal Hypothesis.

\section{Acknowledgement}

I would like to thank my colleagues within the eurasia3angle project, Sonya Oskolskaya for her contribution to the Tungusic dataset and Sander Savelyev for his contribution to the Mongolic and Turkic datasets. The research leading to these results has received funding from the European Research Council (ERC) under the European Union's Horizon 2020 research and innovation programme (grant agreement No 646612) granted to Martine Robbeets.

${ }^{1}$ See Robbeets, this volume: Chapter 3 for an overview of the different classificational models proposed for the Transeurasian family. I refer to the chapters 34 and 40 for a summary of the evidence with regard to verb morphology and basic vocabulary in support of Transeurasian affiliation. 
${ }^{2}$ Cecil Brown informs me that the calculation is based on a lexical similarity score (1LDND\%) of 0.41 . This score is well within the range of chance observance for unrelated languages.

${ }^{3}$ Kuzmin et al. (2012) find the earliest evidence for handmade textiles in East Asia in the Early Neolithic Chertovy Vorota Cave in the Russian Far East (3980-5020 BC). However, the earliest evidence for textile production using spindle whorls goes back to the Xinglongwa culture (6200-5400 BC). The use of spindle whorls is further evidenced for other agricultural societies such as the Zaisanovskaya culture (32001300 BC) in the Southern Primorye, Middle-Late Chulmun culture in Korea (35001000 BC) and Yayoi culture (900 BC-300AD) in Japan.

${ }^{4}$ According to Jeong et al. (2018a), the earliest direct evidence for the adoption of dairy pastoralism on the Eastern steppes comes from the presence of milk protein in the dental calculus of Khövsgöl individuals, as late as 1500-870 BC. 